\title{
The contents of nickel in perennial ryegrass (Lolium perenne L.) as affected by application of multicomponent fertilizers
}

\author{
Beata Draszawka - Bołzan \\ Faculty of Biology, University of Szczecin, 13 Waska Street, 71-415 Szczecin, Poland \\ E-mail address: atkadb@o2.pl
}

\begin{abstract}
Urbanization is the cause of many changes which is taking place in the environment, including those found in the catchment Three multicomponent fertilizers were applied: Polifoska 8, Polifoska 16 and Polimag 306, at the rates of $0.5 ; 1.0$; and $1.5 \mathrm{~g} \mathrm{~N}$ per pot. The total forms of nickel were determined in dry matter of perennial ryegrass with the use of ASA method. The contents of these elements were higher in the fertilized variants as compared to the control. No significant differences were found among the contents of investigated elements compared in plants treated with different multicomponent fertilizers. The increasing rates of nitrogen decreased soil $\mathrm{pH}$ and, thereby, enhanced the availability and concentration of heavy metals in perennial ryegrass. A pot experiment on an acid brown soil was conducted in 1998-2001.
\end{abstract}

Keywords: heavy metals; soil; mineral fertilizer; nickel; perennial ryegrass

\section{INTRODUCTION}

Urbanization is the cause of many changes which is taking place in the environment, including those found in the catchment [4,6-8,10,12,22-26]. With this in mind, an important issue is the proper protection of water reservoirs and also taking action to counter the adverse effects of human activities on the natural environment, including water tanks [4-8,10,12,16, 18,22-25]. The problem of soil heavy metals pollution occurs in Poland locally and applies first of all industrialized areas, but in some areas, in the vicinity of the former or current sources of emissions, soil sometimes exhibit a significant degree of pollution $[1,3,5,7,9$, $11,14,19,21,24,27]$.

Heavy metals occur as contaminants of agricultural and industrial area. Their longlasting results in the accumulation of surface soil layers in the deposition and migrate deeper into the soil profile, right down to the groundwater [20,21,24,27]. Heavy metals in soils may constitute a potential source of danger for plants and for groundwater, and consequently can be incorporated into the food chain [20,23,27]. Download trace of contaminated soils by plants often exceeds their physiological demand, which causes an excess of these elements in soils can act phytotoxic [19,21]. Nickel are metallic elements, the most toxic to plants and animals [19-21]. 


\section{EXPERIMENTAL}

A pot experiment on an acid brown soil was conducted in 1998-2001. Three multicomponent fertilizers were applied: Polifoska 8, Polifoska 16 and Polimag 306, at the rates of $0.5 ; 1.0$; and $1.5 \mathrm{~g} \mathrm{~N}$ per pot. The total forms of nickel were determined in dry matter of perennial ryegrass with the use of ASA method [16,17,19,20]. The contents of these elements were higher in the fertilized variants as compared to the control. No significant differences were found among the contents of investigated elements compared in plants treated with different multicomponent fertilizers $[16,17,19,20]$.

The soil on Which experience has been Carried out to qualified valuation class IVa. Test plant was perennial ryegrass (Lolium perenne L.). After the growth of biological material (Lolium perenne L.), and the mixture mineralization nitric and perchloric acids determined nickel.

\section{RESULTS AND DISCUSSION}

Results of the content of nickel in dry matter of perennial ryegrass (Lolium perenne L.) in Tables 1 to 3 .

Table 1. The content of nickel in dry matter of perennial ryegrass (Lolium perenne $\mathrm{L}$.) $\mathrm{mg} \cdot \mathrm{kg}^{-1} \mathrm{DM}$.

\begin{tabular}{|c|c|c|c|c|c|}
\hline \multirow{2}{*}{$\begin{array}{l}\text { Fertilizers } \\
\text { compared }\end{array}$} & \multirow{2}{*}{ Doses } & \multicolumn{4}{|c|}{ Nickel } \\
\hline & & I & II & III & Mean \\
\hline \multicolumn{2}{|c|}{ Control } & 2,61 & 2,85 & 2,73 & 2,73 \\
\hline \multirow{3}{*}{ Polifoska 8} & $1 d$ & 2,74 & 3,26 & 3,58 & 3,19 \\
\hline & $2 d$ & 2,94 & 3,83 & 2,84 & 3,20 \\
\hline & $3 d$ & 3,61 & 3,97 & 3,82 & 3,80 \\
\hline \multicolumn{2}{|c|}{ Mean } & 3,10 & 3,69 & 3,79 & 3,40 \\
\hline \multicolumn{2}{|c|}{ Minimum } & 2,74 & 3,26 & 2,84 & 3,19 \\
\hline \multicolumn{2}{|c|}{ Maximum } & 3,61 & 3,97 & 3,82 & 3,80 \\
\hline \multicolumn{2}{|c|}{ Standard deviation } & 1,37 & 1,62 & 1,49 & - \\
\hline \multicolumn{2}{|c|}{ Mediana } & 0,95 & 1,45 & 1,83 & - \\
\hline \multicolumn{2}{|c|}{ Coefficient of variation } & 7,63 & 5,92 & 6,84 & - \\
\hline
\end{tabular}


Table 2. The content of nickel in dry matter of perennial ryegrass (Lolium perenne L.) $\mathrm{mg} \cdot \mathrm{kg}^{-1} \mathrm{DM}$.

\begin{tabular}{|c|c|c|c|c|c|}
\hline \multirow{2}{*}{$\begin{array}{c}\text { Fertilizers } \\
\text { compared }\end{array}$} & \multirow{2}{*}{ Doses } & I & II & III & Mean \\
\cline { 3 - 6 } & \multirow{2}{*}{ Control } & 2,86 & 3,69 & 3,57 & 3,37 \\
\hline \multirow{2}{*}{ 1d } & 3,51 & 3,42 & 3,84 & 3,59 \\
\cline { 2 - 6 } Polifoska 16 & $2 \mathrm{~d}$ & 3,85 & 3,79 & 3,53 & 3,72 \\
\cline { 3 - 6 } & $3 \mathrm{~d}$ & 4,24 & 3,87 & 4,19 & 4,10 \\
\hline \multicolumn{2}{|c|}{ Mean } & 3,87 & 3,69 & 3,85 & 3,80 \\
\hline \multicolumn{2}{|c|}{ Minimum } & 3,51 & 3,42 & 3,53 & 3,59 \\
\hline \multicolumn{2}{|c|}{ Maximum } & 4,24 & 3,87 & 4,19 & 4,10 \\
\hline \multicolumn{2}{|c|}{ Standard deviation } & 0,81 & 1,27 & 1,05 & - \\
\hline \multicolumn{2}{|c|}{ Mediana } & 1,03 & 0,95 & 0,83 & - \\
\hline \multicolumn{2}{|c|}{ Coefficient of variation } & 10,8 & 11,4 & 14,9 & - \\
\hline
\end{tabular}

Table 3. The content of nickel in dry matter of perennial ryegrass (Lolium perenne L.) $\mathrm{mg} \cdot \mathrm{kg}^{-1} \mathrm{DM}$.

\begin{tabular}{|c|c|c|c|c|c|}
\hline \multirow{2}{*}{$\begin{array}{l}\text { Fertilizers } \\
\text { compared }\end{array}$} & \multirow{2}{*}{ Doses } & \multicolumn{4}{|c|}{ Nickel } \\
\hline & & I & II & III & Mean \\
\hline \multicolumn{2}{|c|}{ Control } & 3,06 & 3,89 & 3,70 & 3,55 \\
\hline \multirow{3}{*}{ Polimag 306} & $1 d$ & 3,94 & 4,09 & 3,91 & 3,98 \\
\hline & $2 d$ & 4,17 & 4,27 & 3,75 & 4,06 \\
\hline & $3 d$ & 4,73 & 4,49 & 4,05 & 4,42 \\
\hline \multicolumn{2}{|c|}{ Mean } & 4,28 & 4,28 & 3,90 & 4,15 \\
\hline \multicolumn{2}{|c|}{ Minimum } & 3,94 & 4,09 & 3,75 & 3,98 \\
\hline \multicolumn{2}{|c|}{ Maximum } & 4,73 & 4,49 & 4,05 & 4,42 \\
\hline \multicolumn{2}{|c|}{ Standard deviation } & 0,79 & 1,09 & 1,45 & - \\
\hline \multicolumn{2}{|c|}{ Mediana } & 0,79 & 0,92 & 1,17 & - \\
\hline \multicolumn{2}{|c|}{ Coefficient of variation } & 13,1 & 15,4 & 14,7 & - \\
\hline
\end{tabular}


The average nickel content in perennial ryegrass (Lolium perenne L.) sustainable compound fertilisers applied at all was higher compared to the control object (Table 1-3). Comparing the content of nickel in each swath slightly higher than the value found in the second and third cut. In the content of nickel in dry matter of perennial ryegrass the Polifoska 8 it ranged from $2,74-3,97 \mathrm{mg} \cdot \mathrm{kg}^{-1} \mathrm{DM}$. In the content of nickel in dry matter of perennial ryegrass the Polifoska 16 it ranged from $3,42-4,24 \mathrm{mg} \cdot \mathrm{kg}^{-1} \mathrm{DM}$. In the content of nickel in dry matter of perennial ryegrass the Polimag 306 it ranged from $3,75-4,73 \mathrm{mg} \cdot \mathrm{kg}^{-1} \mathrm{DM}$.

The content of nickel in perennial ryegrass (Lolium perenne L.) was mostly higher on objects may receive farm manures fertilisers compared to the control object. Differences in the nickel content of fertilisers applied between were insignificant.

\section{CONCLUSIONS}

- The content of nickel in perennial ryegrass (Lolium perenne L.) was mostly higher on objects may receive farm manures fertilisers compared to the control object.

- In the content of nickel in dry matter of perennial ryegrass the Polifoska 8 it ranged from 2,74- 3,97 $\mathrm{mg} \cdot \mathrm{kg}^{-1} \mathrm{DM}$.

- In the content of nickel in dry matter of perennial ryegrass the Polifoska 16 it ranged from $3,42-4,24 \mathrm{mg} \cdot \mathrm{kg}^{-1} \mathrm{DM}$.

- In the content of nickel in dry matter of perennial ryegrass the Polimag 306 it ranged from $3,75-4,73 \mathrm{mg} \cdot \mathrm{kg}^{-1} \mathrm{DM}$.

- Differences in the nickel content of fertilisers applied between were insignificant.

\section{References}

[1] Azarmi R., Giglou M. T., Taleshmikail R. D., Afr. J. Biotechnol. 7(14) (2008) 2397-2401.

[2] Anke M., Kolloquien des Instituts für Pflanzenernảhrung. Jena 2 (1987) 110-111.

[3] Broos K., Beyens H., Smolders E., Soil Biology \& Biochemistry 37 (2005) 573-579.

[4] Daniszewski P., International Letters of Chemistry, Physics and Astronomy 1 (2012) 13-16

[5] Daniszewski P., International Letters of Chemistry, Physics and Astronomy 2 (2012) $35-41$.

[6] Daniszewski P., International Letters of Chemistry, Physics and Astronomy 2 (2012) 42-45.

[7] Daniszewski P., International Letters of Chemistry, Physics and Astronomy 2 (2012) 46-52.

[8] Daniszewski P., International Letters of Chemistry, Physics and Astronomy 4 (2012) 119-124.

[9] Daniszewski P., International Letters of Chemistry, Physics and Astronomy 5 (2012) $72-79$. 
[10] Daniszewski P., International Letters of Chemistry, Physics and Astronomy 5 (2012) 80-87.

[11] Daniszewski P., Konieczny R., International Letters of Chemistry, Physics and Astronomy 4 (2013) 91-97.

[12] Daniszewski P., Konieczny R., International Letters of Chemistry, Physics and Astronomy 4 (2013) 98-104.

[13] Daniszewski P., International Letters of Chemistry, Physics and Astronomy 7(1) (2013) 60-66.

[14] Daniszewski P., International Letters of Chemistry, Physics and Astronomy 7(1) (2013) 67-72.

[15] Desai V. R., Sabale R. N., Raundal P. V., Agric. Univ. 24(3) (1999) 273-275 .

[16] Kabata-Pendias A., Zesz. Nauk. Kom. PAN Człowiek i środowisko 21 (1998) 9-17.

[17] Kabata-Pendias A., Zesz. Nauk. Kom. PAN Człowiek i środowisko 33 (2000) 1-18.

[18] Kabata-Pendias A., Pendias H., CRC Press, Boca Raton, Fl, USA (2001) 413.

[19] Kalembasa S., Symanowicz B., Chem. Engin. A. 17(7) (2010) 757-764.

[20] Nowak W., Draszawka-Bołzan B., Agricultura 84 (2000) 363-366.

[21] Parthasarathi K., Balamurugan M., Ranganathan L. S., Iran. J. Environ. Health Sci. Eng. 5(1) (2008) 51-58.

[22] Patil S. L., Sheelavantar M. N., Annals Agric. Res. 21(21) (2000) 32-36.

[23] Spiak Z., Romanowska M., Radoła J., Chemistry for Agricultulture 5 (2004) 181-186.

[24] Symanowicz B., Acta Sci. Pol. Agricult. 4(2) (2005) 83-92.

[25] Symanowicz B., Appel Th., Kalembasa S., Polish J. Soil Sci. XXXVII(1) (2004) 11-20.

[26] Symanowicz B., Kalembasa S., Fragm. Agron. 27(1) (2010) 177-185.

[27] Trabelsi D., Pini F., Aouani M. E., Bazzicalupo M., Mengoni A., Letters in Applied Microbiology 48 (2009) 355-361. 